\title{
Analisis Kepuasan Konsumen Terhadap Kualitas Pelayanan Swalayan Dengan Metode Importance Performance Analysis Dan Model Kano
}

\author{
Trisna $^{1)}$, Defi Irwansyah ${ }^{1)}$, Mochamad Ari Saptari ${ }^{2)}$, Maisyaroh $^{1)}$ \\ ${ }^{1)}$ Jurusan Teknik Industri, Fakultas Teknik, Universitas Malikussaleh Jl. Batam Kampus Bukit Indah, \\ Blang Pulo, Muara Satu, Lhokseumawe \\ ${ }^{2)}$ Program Studi Sistem Informasi, Fakultas Teknik, Universitas Malikussaleh JI. Batam Kampus Bukit Indah, \\ Blang Pulo, Muara Satu, Lhokseumawe \\ Corresponding Author: trisna@unimal.ac.id
}

\begin{abstract}
Abstrak-Swalayan merupakan usaha retail modern yang menjual barang kebutuhan sehari-hari. Kualitas pelayanan merupakan hal yang sangat penting bagi swalayan untuk menghadapi persaingan sehingga perlu dilakukan perbaikan. Penelitian ini bertujuan untuk menganalisis kualitas pelayanan suatu swalayan dengan menggunakan metode Importance Performance Analysis (IPA) dan model Kano sehingga dapat diketahui prioritas atribut yang harus diperbaiki sesuai dengan keinginan konsumen. Dari hasil penelitian menunjukkan bahwa prioritas atribut yang harus ditingkatkan kinerjanya oleh pihak swalayan yaitu penunjuk lokasi barang yang jelas, keamanan tempat parkir, terdapat label harga pada produk, harga produk yang ditawarkan sesuai dengan label.
\end{abstract}

Kata Kunci: Swalayan, Kepuasan konsumen, Model Kano, Importance Performance Analysis

\section{Pendahuluan}

Dalam suatu usaha swalayan, kualitas pelayanan merupakan hal yang sangat penting untuk diperhatikan. Pelayanan yang baik akan memberikan kepuasan tersendiri terhadap konsumen. Pada usaha swalayan, memberi pelayanan yang baik bagi konsumen merupakan hal yang sangat penting karena pendapatan usaha diperoleh dari banyaknya barang dibeli oleh konsumen sehingga memperoleh untung. Untuk itu diperlukan upaya peningkatan pelayanan untuk meningkatkan minat konsumen berbelanja pada swalayan. Untuk mewujudkan kepuasan konsumen dibutuhkan kualitas pelayanan sebaik mungkin serta komitmen yang tinggi dari pimpinan maupun para karyawan.

Salah satu kota yang cukup berkembang pesat dalam dunia bisnis modern adalah Kota Lhokseumawe. Mudahnya mendapat izin pendirian retail modern mempengaruhi perkembangan usaha swalayan di kota tersebut. Swalayan X merupakan salah satu usaha yang menyediakan sejumlah produk kebutuhan sehari-hari di Kota Lhokseumawe.

Setiap usaha pasti menginginkan laba secara maksimal, begitu juga dengan Swalayan $X$ ini, tetapi mengingat adanya beberapa masalah tentang pelayanan yang diberikan, seperti sebagian pada label harga produk tidak tersedia, pengutipan biaya parkir, area parkir dan pelayanan dari karyawan yang kurang dalam melayani konsumennya. Untuk itu, perlu dilakukan penelitian pada swalayan mengenai kepuasan konsumen terhadap kualitas pelayanan yang diberikan. Karena kepuasan konsumen dapat meningkatkan kesetiaan dan jumlah konsumen untuk berbelanja dan selanjutnya dapat meningkatkan penjualan.

Model kano merupakan suatu model yang mengkategorikan karakteristik produk atau jasa berdasarkan seberapa baik produk atau jasa tersebut mampu memuaskan kebutuhan konsumen.

Penelitian sebelumnya mengenai model Kano antara lain dilakukan untuk menentukan karateristik produk untuk pengembangan susu kedelai Trisna, Ma'arif, \& Akerman [1]. [2] mengalisis kebutuhan konsumen dengan model Kano. [3] menggunakan model Kano untuk menganalisis kebutuhan konsumen terhadap suatu produk.

Metode IPA bertujuan untuk mengukur hubungan antara persepsi konsumen dan prioritas peningkatan kualitas produk/jasa yang dikenal pula sebagai kuadran.

[4] menggunakan metode IPA untuk menganalisis kualitas pelayanan Samsat keliling kota Bogor. [5] menggunakan metode IPA untuk menganalisis kepuasan konsumen terhadap kualitas pelayanan supermarket. [6] menganalisis kepuasan pelanggan SBU laboratory Cibitung PT. Sucofindo dengan metode IPA.

Uraian penelitian sebelumnya dapat dilihat bahwa sudah banyak melakukan penelitian tentang metode IPA dan model Kano untuk mengukur kualitas suatu pelayanan atau produk. Namun masih sedikit yang menggabungkan metode IPA dan model Kano seperti 
yang dilakukan oleh [7]. Mereka mengintegrasikan metode IPA dan model Kano untuk menganalisis kualitas pelayanan Perusahaan Air minum. Sementara, [8] mengunakan metode IPA dan model Kano untuk meningkatkan kualitas pelayanan perpustakaan.

Masih sedikitnya penelitian yang mengintegrasikan metode IPA dan model KANO menjadi motivasi kami untuk menganalisis kualitas pelayanan swalayan dengan menggunakan kedua metode tersebut. Penelitian ini bertujuan untuk mengetahui atribut atribut yang menjadi prioritas utama dalam kualitas pelayanan swalayan, kategori kano pada atribut prioritas utama dalam kualitas pelayanan swalayan, dan mengintegrasikan metode Importance Performance Analysis (IPA) dan model Kano.

\section{Tinjauan Pustaka}

\subsection{Kepuasan Konsumen}

Kepuasan konsumen adalah tingkat perasaan konsumen setelah membandingkan antara apa yang diterima dan harapannya. Jika seorang pelanggan merasa puas dengan nilai yang diberikan oleh produk atau jasa, maka kemungkinan besar menjadi pelanggan yang setia [9].

\subsection{Kualitas Pelayanan}

Kualitas pelayanan merupakan seberapa besar perbedaan antara kenyataan dan harapan para pelanggan terhadap pelayanan yang mereka terima. Kualitas pelayanan dapat diketahui dengan cara membandingkan persepsi atau harapan para pelanggan atas layanan yang mereka terima [10].

\subsection{Importance Performance Analysis (IPA)}

Metode Importance Performance Analysis (IPA) bertujuan untuk mengukur hubungan antara persepsi konsumen dan prioritas peningkatan kualitas produk/jasa atau dikenal dengan kata lain quadrant analysis. Hubungan tingkat kepentingan dan kepuasan digambarkan pada diagram kartesius seperti ditunjukkan pada Gambar 1.

Tahapan dalam metode Importance Performance Analysis (IPA) adalah berikut:

a. Menentukan tingkat kesesuaian

b. Menghitung rata-rata untuk setiap atribut

c. Menghitung rata-rata seluruh atribut tingkat kepentingandan kinerja yang menjadi batas pada diagram kartesius.

d. Melakukan pemetaan ke dalam diagram kartesius.

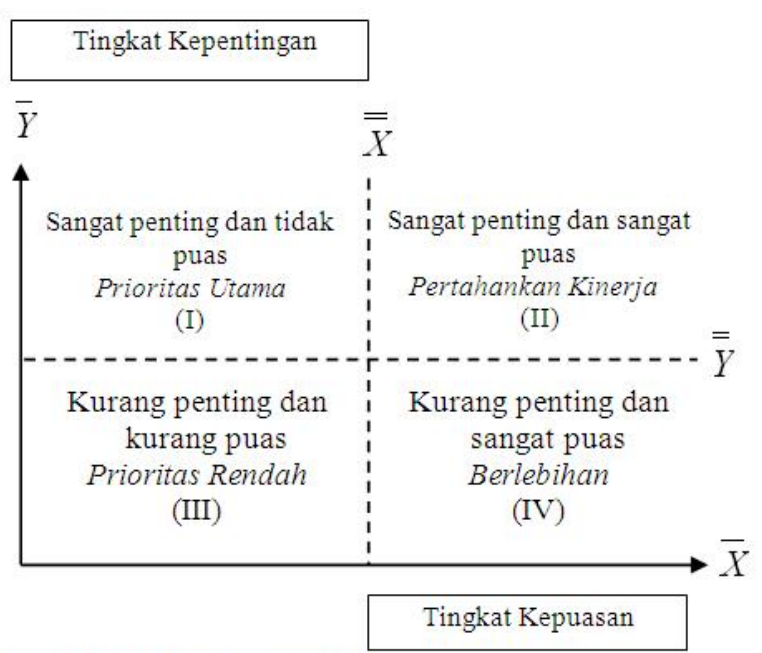

Gambar 1 Diagram kartesius Importance Performance Analysis (IPA)

\subsection{Model Kano}

Model Kano dikembangkan oleh Noriaki Kano (1984) yang bertujuan untuk mengkategorikan atributatribut dari produk maupun jasa berdasarkan seberapa baik produk tersebut mampu memuaskan kebutuhan pelanggan

Atribut-atribut layanan pada model Kano dapat dibagi menjadi beberapa kategori [11]:

1. Must be atau basic needs (M)

Pada kategori ini, konsumen menganggap bahwa atribut tersebut adalah harus ada dalam produk. Pelanggan tidak akan puas bila atribut yang ada dalam kategori ini tidak terpenuhi.

2. One dimensional atau performance needs (O) Kepuasan konsumen akan meningkat jika atribut yang ada dalam kategori ini diberikan, tetapi konsumen juga tidak akan puas jika atribut yang ada dalam kategori ini tidak ada.

3. Attractive (A)

Konsumen akan merasa puas jika atribut yang ada dalam kategori ini diberikan, namun konsumen tidak akan kecewa jika atribut dalam kategori ini tidak ada.

4. Indifferent (I)

Atribut pada kategori ini tidak akan berpengaruh terhadap kenaikan atau penurunan tingkat kepuasan pelanggan atau dengan kata lain pelanggan tidak peduli dengan ada atau tidaknya atribut tersebut.

5. Questionable (Q)

Pada kategori tidak jelas apakah diharapkan atau tidak diharapkan oleh pelanggan atau dengan kata lain terjadi penyangkalan pada jawaban konsumen terhadap pertanyaan yang diberikan.

6. Reverse (R)

Konsumen tidak puas jika terdapat atribut dalam kategori ini, tapi konsumen akan puas jika atribut dalam kategori ini tidak ada. 
a. Menentukan kategori Kano dengan menggunakan rumus Blauth's [12]:

- Jika jumlah nilai $(O+A+M)>$ jumlah nilai (I $+R+Q)$, maka penentuan kategori Kano diperoleh dari nilai yang paling besar dari $(\mathrm{O}, \mathrm{A}, \mathrm{M})$.

- $\quad$ Jika jumlah nilai $(O+A+M)<$ jumlah nilai (I $+R+Q$ ), maka penentuan kategori Kano diperoleh dari nilai paling besar dari (I, R, Q).

- Jika jumlah nilai $(O+A+M)=$ jumlah nilai $(I$ $+R+Q)$, maka kategori Kano diperoleh dari nilai paling besar diantara semua kategori Kano (O, A, M, I, R, Q).

b. Menghitung koefisien tingkat kepuasan dan tingkat kekekcewaan konsumen. Tingkat kepusaan diperoleh dengan menghitung nilai if better than (IBT) yang bernilai antara 0 dan 1 . Semakin mendekati 1 maka konsumen semakin puas. IBT dihitung dengan rumus:

$$
\mathrm{IBT}=\frac{\mathrm{A}+\mathrm{O}}{\mathrm{A}+\mathrm{O}+\mathrm{M}+\mathrm{I}}
$$

Tingkat kekecewaan ditentukan oleh if worse than (IWT) yang bernilai antara 0 dan -1 . Semakin mendekati -1 maka konsumen semakin kecewa. IBT dihitung menggunakan rumus:

$$
\mathrm{IWT}=\frac{\mathrm{M}+\mathrm{O}}{\mathrm{A}+\mathrm{O}+\mathrm{M}+\mathrm{I}}
$$

\section{Hasil dan Pembahasan}

Penelitian menggunakan responden adalah pelanggan aktif yang berbelanja pada swalayan dalam 6 bulan terakhir. Jumlah responden berdasarkan rumus metode slovin dengan tingkat kepercayaan 95\% dan tingkat kesalahan $5 \%$. Hasil uji validitas dan reliabilitas yang dilakukan, diketahui semua atribut dinyatakan valid dan reliable sehingga data dapat digunakan sebagai instrument penelitian.

\subsection{Metode Importance Performance Analysis (IPA)}

Hasil perhitungan rata-rata tingkat kinerja dan tingkat kepentingan setiap atribut dapat dilihat pada Tabel 1, dan kemudian digambarkan ke bentuk diagram kartesius IPA seperti ditunjukkan pada Gambar 2.

Atribut-atribut yang termasuk dalam kuadran prioritas utama yaitu atribut yang dianggap penting tetapi kinerjanya masih dianggap kurang oleh pelanggan dapat dilihat pada Tabel 2. Untuk mengningkatkan pelayanan, atribut pada kuadran ini menjadi prioritas utama pihak manjemen untuk diperbaiki.
Tabel 1 Hasil perhitungan tingkat kinerja dan tingkat kepentingan

\begin{tabular}{|c|c|c|c|c|}
\hline Atribut & $\begin{array}{c}\text { Skor } \\
\text { Kinerja } \\
\left(\mathbf{K}_{\mathbf{i}} \mathbf{)}\right.\end{array}$ & $\begin{array}{c}\text { Skor } \\
\text { Kepentingan } \\
\mathbf{(}_{\mathbf{i}} \mathbf{)}\end{array}$ & $\begin{array}{c}\text { Tingkat } \\
\text { Kinerja }\end{array}$ & $\begin{array}{c}\text { Tingkat } \\
\text { Kepentingan }\end{array}$ \\
\hline TAN1 & 391 & 440 & 3,65 & 4,11 \\
\hline TAN2 & 396 & 440 & 3,70 & 4,11 \\
\hline TAN3 & 405 & 441 & 3,79 & 4,12 \\
\hline TAN4 & 399 & 440 & 3,73 & 4,11 \\
\hline TAN5 & 347 & 446 & 3,24 & 4,17 \\
\hline TAN6 & 351 & 447 & 3,28 & 4,18 \\
\hline TAN7 & 406 & 378 & 3,79 & 3,53 \\
\hline TAN8 & 422 & 431 & 3,94 & 4,03 \\
\hline TAN9 & 400 & 449 & 3,74 & 4,20 \\
\hline REL10 & 372 & 465 & 3,48 & 4,35 \\
\hline REL11 & 418 & 461 & 3,91 & 4,31 \\
\hline REL12 & 286 & 458 & 2,67 & 4,28 \\
\hline REL13 & 423 & 436 & 3,95 & 4,07 \\
\hline REL14 & 433 & 438 & 4,05 & 4,09 \\
\hline REL15 & 229 & 216 & 2,14 & 2,02 \\
\hline RES16 & 424 & 439 & 3,96 & 4,10 \\
\hline RES17 & 422 & 435 & 3,94 & 4,07 \\
\hline RES18 & 415 & 424 & 3,88 & 3,96 \\
\hline RES19 & 411 & 418 & 3,84 & 3,91 \\
\hline ASS20 & 363 & 433 & 3,39 & 4,05 \\
\hline ASS21 & 389 & 424 & 3,64 & 3,96 \\
\hline ASS22 & 411 & 430 & 3,84 & 4,02 \\
\hline EMP23 & 385 & 403 & 3,60 & 3,77 \\
\hline EMP24 & 381 & 384 & 3,56 & 3,59 \\
\hline Rata- & & & 3,61 & 3,96 \\
\hline rata & & & & \\
\hline & & & & \\
\hline
\end{tabular}

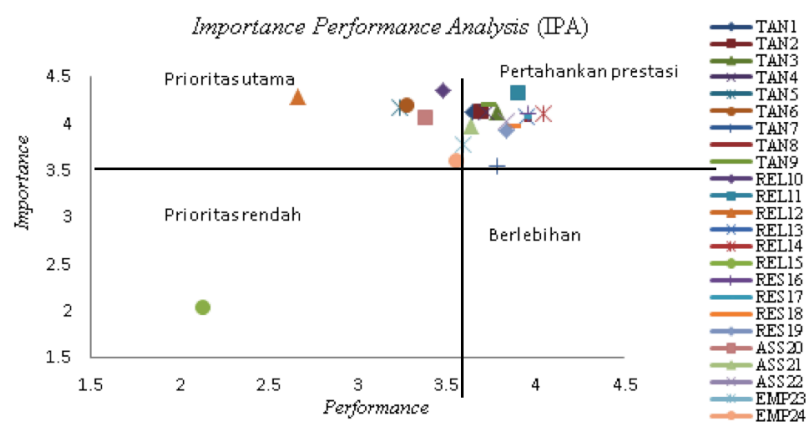

Gambar 2 Diagram Importance Performance Analysis (IPA)

Tabel 2 Atribut pelayanan yang termasuk dalam kategori prioritas utama

\begin{tabular}{|c|c|l|}
\hline \multirow{2}{*}{ Dimensi } & $\begin{array}{c}\text { Kode } \\
\text { Atribut }\end{array}$ & \multicolumn{1}{c|}{ Pertanyaan } \\
\hline \multirow{2}{*}{ Tangible } & TAN5 & Penunjuk lokasi barang yang jelas \\
\cline { 2 - 3 } & TAN6 & $\begin{array}{l}\text { Ketersediaan area parkir yang } \\
\text { memadai dan Teraturnya penataan }\end{array}$ \\
\hline \multirow{2}{*}{ Reliability } & REL10 & Keamanan tempat parkir \\
\cline { 2 - 3 } Assurance & REL12 & Terdapat label harga pada produk \\
\hline ASS20 & $\begin{array}{l}\text { Harga produk yang ditawarkan sesuai } \\
\text { dengan label }\end{array}$ \\
\hline
\end{tabular}

Atribut pelayanan Swalayan $X$ yang termasuk dalam kategori pertahankan prestasi dan harus dipertahankan kinerjanya karena sesuai dengan keinginan konsumen yaitu dapat dilihat pada Tabel 3.

Atribut pelayanan Swalayan $X$ yang termasuk dalam kategori prioritas rendah dengan tingkat kepentingan rendah dan kenyatannya kinerjanya tdak terlau 
istimewa dengan tingkat kepuasan yang rendah pula yaitu dapat dilihat pada Tabel 4.

Tabel 3 Atribut pelayanan yang termasuk dalam kategori pertahankan prestasi

\begin{tabular}{|c|c|c|}
\hline Dimensi & $\begin{array}{l}\text { Kode } \\
\text { Atribut }\end{array}$ & Pertanyaan \\
\hline \multirow{6}{*}{ Tangible } & TAN1 & Suhu ruangan sangat nyaman \\
\hline & TAN2 & Lampu yang terang \\
\hline & TAN3 & $\begin{array}{l}\text { Tata letak dan penataan barang yang } \\
\text { teratur }\end{array}$ \\
\hline & TAN4 & Jumlah kasir yang mencukupi \\
\hline & TAN8 & Kelengkapan produk yang ditawarkan \\
\hline & TAN9 & $\begin{array}{l}\text { Kebersihan di dalam dan di luar } \\
\text { ruangan }\end{array}$ \\
\hline \multirow[t]{3}{*}{ Reliability } & REL11 & $\begin{array}{l}\text { Harga produk yang ditawarkan cukup } \\
\text { bersaing dengan kompetitor } \\
\text { setempat }\end{array}$ \\
\hline & REL13 & $\begin{array}{l}\text { Adanya potongan harga yang } \\
\text { diberikan untuk beberapa jenis } \\
\text { produk }\end{array}$ \\
\hline & REL14 & $\begin{array}{l}\text { Kemampuan staf kasir menghitung } \\
\text { dengan teliti }\end{array}$ \\
\hline Responsiveness & RES16 & $\begin{array}{l}\text { Cepat tanggap karyawan melayani } \\
\text { konsumen berbelanja }\end{array}$ \\
\hline & RES19 & Lokasi mudah dijangkau \\
\hline Assurance & ASS22 & $\begin{array}{l}\text { Karyawan bersedia membantu } \\
\text { mengantarkan barang belanjaan } \\
\text { konsumen ke kendaraan konsumen }\end{array}$ \\
\hline
\end{tabular}

Tabel 4 Atribut pelayanan yang termasuk dalam kategori prioritas rendah

\begin{tabular}{ccl}
\hline Dimensi & Kode Atribut & \multicolumn{1}{c}{ Pertanyaan } \\
\hline Reliability & REL15 & $\begin{array}{l}\text { Pengutipan biaya parkir kendaraan } \\
\text { Sistem hadiah yang secara langsung } \\
\text { (potongan harga/voucher) maupun } \\
\text { tidak langsung (undian) }\end{array}$ \\
Emphaty & EMP23 & $\begin{array}{l}\text { Pelayanan terhadap keluhan } \\
\text { konsumen berbelanja }\end{array}$ \\
\hline
\end{tabular}

Atribut pelayanan Swalayan $\mathrm{X}$ yang termasuk dalam kategori berlebihan dengan tingkat kepentingan rendah dan dirasakan konsumen terlalu berlebihan yaitu dapat dilihat pada Tabel 5.

Tabel 5 Atribut pelayanan yang termasuk dalam kategori berlebihan

\begin{tabular}{|c|c|c|}
\hline Dimensi & $\begin{array}{c}\text { Kode } \\
\text { Atribut }\end{array}$ & Pertanyaan \\
\hline Tangible & TAN7 & $\begin{array}{l}\text { Jumlah keranjang belanjaan yang } \\
\text { tersedia }\end{array}$ \\
\hline & RES18 & $\begin{array}{l}\text { Karyawan berkenan membantu } \\
\text { konsumen dalam memilih produk } \\
\text { yang diinginkan }\end{array}$ \\
\hline Responsivness & RES19 & $\begin{array}{l}\text { Karyawan bersedia membantu } \\
\text { mengantarkan barang belanjaan } \\
\text { konsumen ke kendaraan } \\
\text { konsumen }\end{array}$ \\
\hline Assurance & ASS21 & $\begin{array}{l}\text { Karyawan yang sopan, ramah, } \\
\text { tertib, rapi dan lain lain }\end{array}$ \\
\hline
\end{tabular}

\section{Model Kano}

Hasil perhitungan nilai koefisien kepuasan konsumen dengan If Better Than (IBT) dan If Worse Than (IWT) ditunjukkan pada Tabel 6.

Berdasarkan hasil dari perhitungan koefisien kepuasan konsumen, dipeoleh hasil If Better Than (IBT) Copyright (O2019 Department of Industrial Engineering. All rights reserved. dan If Worse Than (IWT), untuk tiap-tiap atribut. Maka selanjutnya grafik koefisien kepuasan konsumen Kano dapat dilihat pada Gambar 3.

Tabel 6 Koefisien kepuasan konsumen Kano

\begin{tabular}{crrrrrrrr}
\hline Atribut & A & M & O & R & Q & I & IBT & IWT \\
\hline TAN1 & 0 & 12 & 95 & 0 & 0 & 0 & 0,89 & $-1,00$ \\
TAN2 & 0 & 13 & 94 & 0 & 0 & 0 & 0,88 & $-1,00$ \\
TAN3 & 1 & 12 & 94 & 0 & 0 & 0 & 0,89 & $-0,99$ \\
TAN4 & 0 & 11 & 96 & 0 & 0 & 0 & 0,90 & $-1,00$ \\
TAN5 & 1 & 23 & 83 & 0 & 0 & 0 & 0,79 & $-0,99$ \\
TAN6 & 0 & 18 & 89 & 0 & 0 & 0 & 0,83 & $-1,00$ \\
TAN7 & 0 & 5 & 102 & 0 & 0 & 0 & 0,95 & $-1,00$ \\
TAN8 & 5 & 9 & 93 & 0 & 0 & 0 & 0,92 & $-0,95$ \\
TAN9 & 5 & 6 & 96 & 0 & 0 & 0 & 0,94 & $-0,95$ \\
REL10 & 2 & 15 & 90 & 0 & 0 & 0 & 0,86 & $-0,98$ \\
REL11 & 16 & 6 & 85 & 0 & 0 & 0 & 0,94 & $-0,85$ \\
REL12 & 1 & 35 & 71 & 0 & 0 & 0 & 0,67 & $-0,99$ \\
REL13 & 15 & 10 & 81 & 1 & 0 & 0 & 0,91 & $-0,86$ \\
REL14 & 2 & 9 & 96 & 0 & 0 & 0 & 0,92 & $-0,98$ \\
REL15 & 0 & 4 & 18 & 85 & 0 & 0 & 0,82 & $-1,00$ \\
RES16 & 3 & 5 & 98 & 1 & 0 & 0 & 0,95 & $-0,97$ \\
RES17 & 4 & 7 & 96 & 0 & 0 & 0 & 0,93 & $-0,96$ \\
RES18 & 6 & 13 & 88 & 0 & 0 & 0 & 0,88 & $-0,94$ \\
RES19 & 8 & 10 & 89 & 0 & 0 & 0 & 0,91 & $-0,93$ \\
ASS20 & 6 & 15 & 86 & 0 & 0 & 0 & 0,86 & $-0,94$ \\
ASS21 & 5 & 12 & 90 & 0 & 0 & 0 & 0,89 & $-0,95$ \\
ASS22 & 16 & 14 & 77 & 0 & 0 & 0 & 0,87 & $-0,85$ \\
EMP23 & 36 & 9 & 61 & 1 & 0 & 0 & 0,92 & $-0,66$ \\
EMP24 & 35 & 6 & 65 & 1 & 0 & 0 & 0,94 & $-0,67$ \\
\hline & & Jumlah & & & & $\mathbf{2 1 , 2 6}$ & $-\mathbf{2 2 , 4 1}$ \\
& & Rata-rata & & & & $\mathbf{0 , 8 9}$ & $-\mathbf{0 , 9 3}$ \\
\hline
\end{tabular}

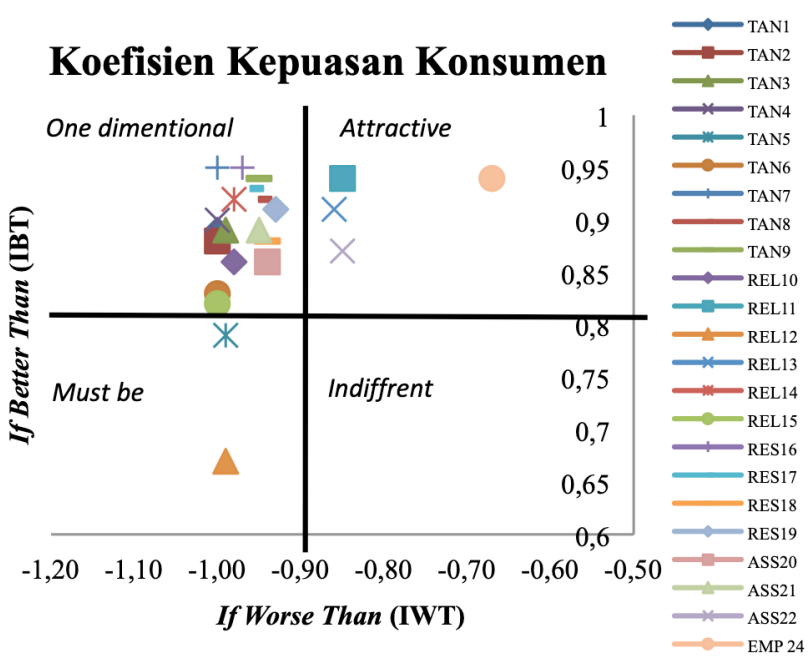

Gambar 3 Diagram kepuasan konsumen Kano

Berdasarkan diagram koefisien kepuasan konsumen diatas, maka atribut-atribut pelayanan dapat dikelompokkan pada masing-masing dimensi. Atribut-atribut yang termasuk dalam one dimentional terdapat 11 atribut yaitu: suhu ruangan sangat nyaman, tata letak dan penataan barang yang teratur, Jumlah kasir yang mencukupi, kelengkapan produk yang ditawarkan, kebersihan di dalam dan di luar ruangan, kemampuan staf kasir menghitung dengan teliti, cepat tanggap karyawan melayani konsumen berbelanja, lokasi mudah dijangkau, jumlah keranjang

Industrial Engineering Journal Vol.8 No.1 (2019) 16-21 
belan-jaan yang tersedia, kesediaan karyawan membantu mengantarkan barang belanjaan kendaraan konsumen, dan karyawan yang sopan, ramah, tertib, rapi, dan lain-lain. Atribut-atribut pada kategori ini akan meningkat kepuasan konsumen bila diberikan, tetapi konsumen tidak akan puas jika atribut yang ada dalam kategori ini tidak ada.Oleh karena itu atributatribut dalam kategori ini apabila sudah terpenuhi maka dapat dipertahankan, sedangkan bila belum terpenuhi, maka harus ebih ditingkatkan.

Untuk kategori attractive terdapat 4 atribut, yaitu: harga produk yang ditawarkan cukup bersaing dengan pesaing setempat, adanya potongan harga yang diberikan untuk beberapa jenis produk, adanya pemberian hadiah secara langsung maupun tidak langsung, dan pelayanan terhadap keluhan konsumen berbelanja. Atribut-atribut pada kategori ini memberi kepuasan kepada konsumen, namun konsumen tidak akan kecewa jika atribut tersebut tidak diberikan. terang, dan pengutipan biaya parkir kendaraan. Atribut-atribut pada kategori ini harus ada sehingga dapat memberi kepuasan pada konsumen. Bila atribut tersebut masih dianggap kurang bagi konsumen, maka pihak swalayan harus memperbaikinya.

Kategori indifferent terdapat 1 atribut, yaitu: karyawan bersedia membantu mengantarkan barang belanjaan konsumen ke kendaraan konsumen. Atribut pada kategori tersebut tidak akan berpengaruh terhadap kenaikan atau penurunan tingkat kepuasan pelanggan. Dalam rangka meningkatkan kepuasan pelanggan, atribut tersebut dapat diabaikan.

Integrasi atribut pada Importance Performance Analysis (IPA) dan model Kano dilakukan untuk mengetahui atribut mana yanga perlu dipertahankan, ditingkatkan atau dikurangi. Integrasi selengkapnya dapat dilihat pada Tabel 7.

Berdasarkan hasil pemetaan Importance Performance

Tabel 7 Integrasi Importance Performance Analysis (IPA) dan model Kano

\begin{tabular}{|c|c|c|c|c|}
\hline $\begin{array}{l}\text { Kode } \\
\text { Atribut }\end{array}$ & Pelayanan & Kategori IPA & $\begin{array}{l}\text { Kategori } \\
\text { Kano }\end{array}$ & Perbaikan \\
\hline TAN5 & Penunjuk lokasi barang yang jelas & Prioritas Utama & $\mathrm{M}$ & Ditingkatkan \\
\hline TAN6 & Ketersediaan area parkir yang memadai dan teraturnya penataan & Prioritas Utama & M & Ditingkatkan \\
\hline REL10 & Keamanan tempat parkir & Prioritas Utama & M & Ditingkatkan \\
\hline REL12 & Terdapat label harga pada produk & Prioritas Utama & M & Ditingkatkan \\
\hline ASS20 & Harga produk yang ditawarkan sesuai dengan label & Prioritas Utama & M & Ditingkatkan \\
\hline TAN1 & Suhu ruangan sangat nyaman & $\begin{array}{l}\text { Pertahankan } \\
\text { Prestasi }\end{array}$ & 0 & Pertahankan \\
\hline TAN2 & Cahaya ruang ruang terang & $\begin{array}{l}\text { Pertahankan } \\
\text { Prestasi }\end{array}$ & M & Pertahankan \\
\hline TAN3 & Tata letak dan penataan barang yang teratur & $\begin{array}{l}\text { Pertahankan } \\
\text { Prestasi }\end{array}$ & $\mathrm{O}$ & Pertahankan \\
\hline TAN4 & Jumlah kasir yang mencukupi & $\begin{array}{l}\text { Pertahankan } \\
\text { Prestasi }\end{array}$ & $\mathrm{O}$ & Pertahankan \\
\hline TAN8 & Kelengkapan produk yang ditawarkan & $\begin{array}{l}\text { Pertahankan } \\
\text { Prestasi }\end{array}$ & $\mathrm{O}$ & Pertahankan \\
\hline TAN9 & Kebersihan di dalam dan di luar ruangan & $\begin{array}{l}\text { Pertahankan } \\
\text { Prestasi }\end{array}$ & $\mathrm{O}$ & Pertahankan \\
\hline REL11 & Harga produk yang ditawarkan cukup bersaing dengan pesaing setempat & $\begin{array}{l}\text { Pertahankan } \\
\text { Prestasi }\end{array}$ & A & Pertahankan \\
\hline REL13 & Adanya potongan harga yang diberikan untuk beberapa jenis produk & $\begin{array}{c}\text { Pertahankan } \\
\text { Prestasi }\end{array}$ & A & Pertahankan \\
\hline REL14 & Kemampuan staf kasir menghitung dengan teliti & $\begin{array}{l}\text { Pertahankan } \\
\text { Prestasi }\end{array}$ & O & Pertahankan \\
\hline RES16 & Cepat tanggap karyawan melayani konsumen berbelanja & $\begin{array}{l}\text { Pertahankan } \\
\text { Prestasi }\end{array}$ & $\mathrm{O}$ & Pertahankan \\
\hline RES19 & Lokasi mudah dijangkau & $\begin{array}{l}\text { Pertahankan } \\
\text { Prestasi }\end{array}$ & $\mathrm{O}$ & Pertahankan \\
\hline ASS22 & $\begin{array}{l}\text { Karyawan bersedia membantu mengantarkan barang belanjaan } \\
\text { konsumen ke kendaraan konsumen }\end{array}$ & $\begin{array}{l}\text { Pertahankan } \\
\text { Prestasi }\end{array}$ & 1 & Pertahankan \\
\hline REL15 & Pengutipan biaya parkir kendaraan & Prioritas Rendah & M & Dikurangi \\
\hline EMP23 & Adanya pemberian hadiah secara langsung maupun tidak langsung & Prioritas Rendah & A & Dikurangi \\
\hline EMP24 & Pelayanan terhadap keluhan konsumen berbelanja & Prioritas Rendah & A & Dikurangi \\
\hline TAN7 & Jumlah keranjang belan-jaan yang tersedia & Berlebihan & $\mathrm{O}$ & Dikurangi \\
\hline RES19 & $\begin{array}{l}\text { Kesediaan karyawan membantu mengantarkan barang belanjaan } \\
\text { kendaraan konsumen }\end{array}$ & Berlebihan & $\mathrm{O}$ & Dikurangi \\
\hline ASS21 & Karyawan yang sopan, ramah, tertib, rapi, dan lain-lain & Berlebihan & $\mathrm{O}$ & Dikurangi \\
\hline
\end{tabular}

Untuk kategori must be terdapat 8 atribut, yaitu: Penunjuk lokasi barang yang jelas, ketersediaan area parkir yang memadai dan teraturnya penataan, terdapat label harga pada produk, harga produk yang ditawarkan sesuai dengan label, cahaya ruang ruang
Analysis (IPA) dan model Kano, ada 4 atribut yang harus ditingkatkan yaitu dengan kode atribut TAN5, TAN6, REL10 dan REL12. Terdapat 13 atribut layanan yang harus dipertahankan yaitu dengan kode atribut TAN1, TAN2, TAN3, TAN4, TAN8, TAN9, REL11, REL13, REL14, 
RES16, RES19 dan ASS22. 7 atribut layanan yang harus dikurangi untuk memenuhi kepuasan konsumen berdasarkan hasil yang diperoleh yaitu dengan kode atribut REL15, EMP23, EMP24, TAN7, RES18, RES19, dan ASS21.

\section{SIMPULAN}

Metode Kano dan IPA digunakan pada penelitian ini untuk menganalisis kepuasan konsumen terhadapa pelayanan swalayan. Kedua metode tersebut mengidentifikasi atribut pelayanan yang harus dipertahankan karena sudah sesuai harapan dan atribut yang ditingkatkan karena belum sesua harapan konsumen. Hasil analisis menjadi acuan bagi manajemen swalayan untuk memperbaiki pelayanan, sehingga dapat meningkatkan kepuasan konsumen. Berdasarkan hasil integrasi metode IPA dan model Kano, ada 5 atribut pelayanan yang harus ditingkatkan karena belum memenuhi harapan konsumen, yaitu penunjuk lokasi barang yang jelas, ketersediaan area parkir yang memadai dan teratur, serta keamanan tempat parkir.

\section{SARAN}

Berdasarkan penelitian yang telah dilakukan, maka penulis memberikan saran sebagai berikut:

1. Diharapkan pihak Swalayan Sejahtera dapat meningkatkan kinerja atribut pelayanannya berdasarkan harapan dari konsumen.

2. Penelitian ini dapat dilanjutkan dengan menganalisis faktor-faktor penyebab rendahnya beberapa kinerja atribut pelayanan yang penting, sehingga peningkatan kualitas pelayanan Swalayan $X$ dapat dikedepankan sebagai sektor publik.

\section{DAFTAR PUSTAKA}

[1] Trisna, S. Ma'arif, and Y. Akerman, "Strategi Pengembangan Produk Susu Kedelai dengan Penentuan Karakteristik Produk," J. Tek. Ind., pp. 157-168, 2013.

[2] Q. Xu, R. J. Jiao, X. Yang, M. Helander, H. M. Khalid, and A. Opperud, "An analytical Kano model for customer need analysis," Des. Stud., vol. 30, no. 1, pp. 87-110, 2009.

[3] T. Wang and P. Ji, "Understanding customer needs through quantitative analysis of Kano's model," Int. J. Qual. Reliab. Manag., vol. 27, no. 2, pp. 173-184, 2010.

[4] T. Kusumah and K. Sisilia, "Analisis Kepuasan Konsumen Terhadap Kualitas Pelayanan Publik Pada Samsat Keliling Kota Bogor Dengan Metode Importance Performance Analysis," eProceedings Manag., vol. 2, no. 2, 2015.

[5] M. Yola and D. Budianto, "Analisis kepuasan konsumen terhadap kualitas pelayanan dan harga produk pada supermarket dengan menggunakan metode Importance Performance Analysis (IPA)," J. Optimasi Sist. Ind., vol. 12, no. 12, pp. 301-309, 2013.

[6] J. O. Ong and J. Pambudi, "Analisis kepuasan pelanggan dengan Importance Performance Analysis di SBU Laboratory Cibitung PT Sucofindo (Persero)," J@ TI UNDIP J. Tek. Ind., vol. 9, no. 1, pp. 1-10, 2014.

[7] N. B. Puspitasari, H. Suliantoro, and L. Kusumawardhani, "Analisis kualitas pelayanan dengan menggunakan integrasi Importance Performance Analysis (IPA) dan model Kano (studi kasus di PT. Perusahaan Air minum Lyonnaise Jaya Jakarta)," J@TI UNDIP J. Tek. Ind., vol. 5, no. 3, pp. 185-198, 2010.

[8] S. A. F. Nengsih, R. Lestari, and R. Husna, "Integrasi Metode Importance Performance Analysis Dan Model Kano Dalam Peningkatan Kualitas Pelayanan (Studi Kasus: Perpustakaan Universitas Andalas)," J. Mat. UNAND, vol. 5, no. 3, 2016.

[9] H. Umar, Riset Pemasaran Dan Perilaku Konsumen. Jakarta: PT. Gramedia, 2003.

[10] F. Tjiptono, Strategi Pemasaran. Yogyakarta: Andi Offset, 2001.

[11] S. Hanoum, "Prioritizing Healthcare Service Attributes. Comparing Importance Performance Analysis and Kano model," Institut Teknologi Surabaya, 2009.

[12] Walden, “Kano's Methods for Understanding Customer Defined Quality," Cent. Qual. Manag. J., vol. 2, 1993. 